\title{
Rice Germ Oil
}

National Cancer Institute

\section{Source}

National Cancer Institute. Rice Germ Oil. NCI Thesaurus. Code C107354.

The oil extracted from the germ and inner husk of Oryza sativa grains. Rice bran oil is used as a cooking oil and as a substitute for carnauba wax in cosmetics, confectionery, shoe creams and polishing compounds. 